\title{
Znamo li koristiti IKT u svrhu podrške uvođenju inovativnog okružja za učenje?
}

\author{
Maja Vičič Krabonja \\ Srednja ekonomska šola in gimnazija Maribor \\ Trg Borisa Kidriča 3, 2000 Maribor \\ maja.vicic1@guest.arnes.si
}

\author{
Magdalena Šverc \\ Zavod Antona Martina Slomška \\ Vrbanska cesta 30, 2000 Maribor \\ magdalena.sverc@gmail.com
}

\section{Sažetak}

Uvođenje tehnologije u nastavu sve je češće prisutno ne samo u poučavanju već $i$ u učenju. U projektu „Inovativno okružje za učenje uz podršku IKT-a" cilj je uvođenja tehnologije potpora transformaciji nastave tako da se učenicima u osnovnoj i srednjoj školi pruže mogućnosti za učenje u kojima stječu znanje i razvijaju kompetencije. Učitelji pritom trebaju poznavati alate kojima mogu procijeniti jesu li aktivnosti podržane IKT-om primjerene za postizanje postavljenih ciljeva te omogućuju li transformaciju nastave. U prilogu istražujemo tri modela koji bi učiteljima mogli u tome pomoći. Na temelju analize 68 predanih primjera dobre prakse ustanovili smo da je za učitelje u projektu "Inovativno okružje za učenje uz podršku IKT-a" najprimjerenija ljestvica RAT, uz kontinuirano preispitivanje dodane vrijednosti koju primijenjena tehnologija donosi u proces poučavanja i učenja.

Ključne riječi: Inovativna okružja za učenje; aktivnosti podržane IKT-om; R.A.T. model; ITL rubrike; SAMR model.

\section{Uvod}

Većina stručnjaka se danas slaže da je uvođenje promjena u obrazovanje nužno da bi škola mogla pomoći rješavati izazove 21 . stoljeća. Znanja koja su bila temelj napretka u 19. i 20. stoljeću nisu više dovoljna te je vidljivo da su danas kompetencije koje omogućavaju cjeloživotno učenje i brzu prilagodbu promjenljivim okolnostima odgovor na konkurentnu bitku pojedinca, a s njim i društva u globalnom svijetu.
Ken Robinson kaže: „Digitalne tehnologije preoblikuju naš rad, igru, mišljenje, osjećaje $\mathrm{i}$ međuljudske odnose. Ta je revolucija tek počela. Stari obrazovni sustavi nisu bili planirani s tim svijetom na umu. Ako ih budemo poboljšavali podizanjem konvencionalnih standarda, nećemo se moći boriti s izazovima koji su pred nama." (Robinson, Aronica, 2015, str. 17).

Razvijanje, ispitivanje te primjena suvremenih didaktičkih koncepata i modela već je neko vrijeme konstanta školskog prostora u Europi, pa 
tako i u Sloveniji. To je povezano prije svega $s$ generacijom milenijalaca, i prilagođavanjem zahtjevima digitalnog doba u kojem živimo i za kojeg osposobljavamo osnovnoškolske i srednjoškolske učenike te studente. Uključivanje suvremene informacijsko-komunikacijske tehnologije (IKT) u poučavanje i učenje nije više upitno. Cilj našeg rada bio je ustanoviti imamo li mi učitelji dovoljno pedagoškog znanja za ciljanu i smislenu, učinkovitu implementaciju IKT-a u nastavu.

Kako bismo odgovorili na to pitanje, pregledali smo 71 primjer planiranja nastave uz podršku IKTa, koje su pripremili učitelji u projektu „Inovativno okružje za učenje uz podršku IKT-a“. Njihovom analizom namjeravali smo ustanoviti koji je od tri korištena modela (korelacija između planiranih aktivnosti i ostvarivanja ciljeva nastave, RAT model i ITL rubrike) prikladan za evaluaciju implementacije IKT-a u nastavu s ciljem njene transformacije u smislu pružanja mogućnosti za učenje u kojima učenici stječu znanje i razvijaju kompetencije.

\section{Inovativno okružje za učenje}

Izvješće Innovative Learning Environment definira okružje za učenje kao organski, holistički koncept koji uključuje aktivnosti $i$ ishode učenja te prerasta školu u vremenu i prostoru; on predstavlja kontekst unutar kojeg se odvija učenje (OECD, 2013, str. 22).

Inovativno okružje za učenje uz podršku IKT-a omogućuje primjenu inovativne pedagogije 1:1, pri čemu scenariji učenja ističu kako možemo mobilne uređaje koristiti za potporu različitim strategijama učenja; uvode se elementi formativnog praćenja te se uvažava razvoj novih kompetencija uslijed učenja uz primjenu tehnologije, a učenje se u vremenu i prostoru proširuje izvan učionice (Aberšek i sur., 2016).

$\mathrm{U}$ projektu Inovativno okružje za učenje uz podršku IKT-a razumijemo inovativno okružje za učenje kao kvalitetne mogućnosti učenja koje učenika stavljaju u središte procesa učenja te mu omogućavaju aktivnosti kojima gradi svoje znanje te razvija kompetencije.
Ishodišta uvođenja elastičnih oblika učenja i inovativnih okružja za učenje (uz podršku IKT-a), koja podržavaju razvijanje kompetencija, slijede višedimenzionalni koncept (Bocconi, Kampylis, Punie, 2012) te su razvrstani u osam područja koja čine cjelovit nacrt za promjene obrazovnog sustava: učenje, poučavanje, vrednovanje, sadržaj i kurikulum, organizacija, vođenje i vrijednosti, povezanost i infrastruktura, pri čemu su barem prve tri usko povezane sa stručnim usavršavanjem učitelja te njihovom spremnošću na prihvaćanje, kao i njihovom osnaženošću za uvođenje promjena.

Kvaliteta rada učitelja u razredu uvjetovana je znanjem i iskustvom koje budući učitelji steknu tijekom studija, kao i trajnim usavršavanjem na radnome mjestu. Istovremeno, međunarodna istraživanja ukazuju na to da metode koje učitelji koriste u razredu u većoj mjeri ovise o okružju i kulturi poučavanja u kojoj su rasli, nego o vlastitome obrazovanju. Tek rijetki među njima prerastu način poučavanja na koji su sami bili poučavani (Stigler, Hiebert, 2009).

Većina učitelja danas još nije dio milenijske generacije i poučavanje uz pomoć tehnologije za njih dakle nije samo po sebi razumljivo. Stoga je tim važnije da oni budu refleksivni istraživači vlastite prakse te da poznaju svoje prednosti $i$ nedostatke u pitanju sadržaja, pedagogije i uporabe tehnologije. Model TPACK na Slici 1 (tehnološka (T), pedagoška (P) i sadržajna (C) znanja učitelja) je osnova za dobro poučavanje uz pomoć tehnologije te zahtijeva razumijevanje koncepta uporabe tehnologije, uporabu pedagoških tehnika koje uključuju tehnologije za konstruktivne načine poučavanja, znanje o tome kako učitelj može pomoći učenicima otkloniti teškoće pomoću tehnologije, i kako učiniti učenje težim ili lakšim, zatim poznavanje prethodnog znanja i teorija epistemologije učenika, znanje o tome kako učitelj može uporabom tehnologije nadograditi postojeće znanje učenika, i kako može razvijati nove epistemologije ili osnažiti postojeće (Mishra, Koehler, Matthews, 2006, str. 1029). 


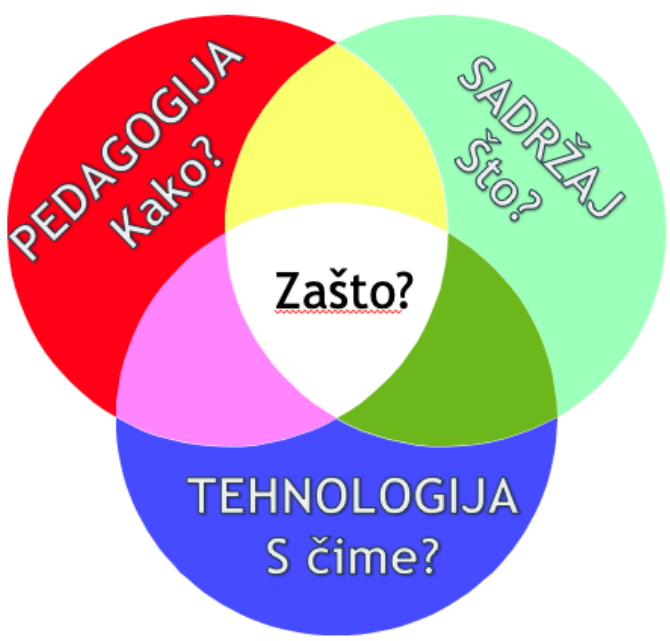

Slika 1. Shema TPACK modela

Kompetencije koje učitelj treba za uvođenje inovativnog okružja za učenje su mnoge i raznolike:

- Poznavanje područja kompetencija 21. stoljeća, kojima učitelj sam mora dobro ovladati.

- Ovladavanje kurikulumom pojedinog predmeta do te mjere da zna odabrati sadržaje kojima može specifično razvijati pojedinu kompetenciju.

- Sposobnost planiranja i suradnje s ostalim učiteljima u razrednome vijeću što omogućuje sinergiju učinaka i sprječava podvajanje odnosno prezasićenost određenim elementima.

- Pedagoška i didaktička znanja koja učitelju omogućuju organizirati nastavu usmjerenu učeniku uz kontinuirano vrednovanje i povratno informiranje.

- Ovladavanje uporabom uređaja te sposobnost traženja i vrednovanja aplikacija, primjerenih za provedbu određenih aktivnosti i postizanje općih, odnosno specifičnih, ciljeva predmeta.

Europski referentni okvir za edukatore (Redecker, 2017) predlaže 6 područja digitalnih kompetencija kojima učitelji moraju ovladati: stručna angažiranost, digitalni izvori, digitalna pedagogija, digitalno vrednovanje, osnaživanje učenika i omogućavanje razvoja digitalnih kompetencija učenika.

\section{Uporaba IKT-a u poučavanju i učenju}

Richard E. Mayer (Mayer, 2013, str. 167) je učenje tehnologijom opisao kao „situacije učenja u kojima iskustvo učenja stvaramo pomoću fizičkih uređaja kao što su računalo i internet Istovremeno je upozorio na bitnu razliku između dva pristupa učenju uz pomoć tehnologije:

- tehnologijom usmjereno učenje razumije kao aktivnost čiji je cilj upotrijebiti tehnologiju kod poučavanja i tehnologija je ta koja omogućuje pristup poučavanju;

- učeniku usmjeren pristup učenju uz potporu tehnologije jest taj koji pomaže pojedincu pri učenju, cilj kojeg je dakle prilagoditi tehnologiju za poticanje učenja.

Hattie (Hattie, 2018, str. 322-325) je u svom popisu 150 utjecaja na ishode učenja koji je sastavio na temelju istraživanja više od 800 metaanaliza uvrstio i neke utjecaje koji su povezani s uvođenjem tehnologije. Ponegdje je uporaba tehnologije moguće prikrivena (npr. vizualne/audiovizualne metode na 110. mjestu), a eksplicitno se spominje kod slijedećih utjecaja: interaktivne video-metode na 46. mjestu (s nadprosječnim faktorom utjecaja 0,52 ), računalno podržano poučavanje na 77 . mjestu (sa podprosječnim faktorom utjecaja 0,37), programirano poučavanje na 105. mjestu (faktor utjecaja 0,23) i mrežno učenje na 124. mjestu (faktor utjecaja 0,18).

Pristup tehnologiji dakle još ne znači da će učenje samim time biti i učinkovitije, iako neki dokazuju da uporaba tehnologije koju učenici koriste $u$ svakodnevnom životu, $u$ nastavi povećava njihovu motivaciju i osjećaj uključenosti (Francis, 2017), (Godzicki i sur., 2013). Novije istraživanje među slovenskim srednjoškolcima pokazalo je da $50 \%$ anketiranih učenika u školi upotrebljava IKT nekoliko puta tjedno, $21 \%$ čak svaki dan. Manje poticajan je podatak da je $42 \%$ te uporabe ograničen samo na jedan ili dva nastavna predmeta, što ukazuje na vrlo neravnomjerno uključivanje uporabe IKT-a u poučavanje (Stanojev, Florjančič, 2018). 


\section{Kada i kako koristiti tehnologiju u nastavi?}

Utjecaj tehnologije na učinkovitost učenja ovisan je i o načinu njene uporabe. Pritom postoje različiti modeli kojima učitelji mogu provjeriti smislenost i učinkovitost uporabe tehnologije. $\mathrm{Na}$ stvaranje kvalitetnih mogućnosti učenja uz podršku tehnologije, učitelje već više od desetljeća potiču različiti modeli.

Dr. Joan Hughes razvija RAT model od 1998. godine kako bi učiteljima omogućila kritički pristup donošenju odluka o integraciji tehnologije u nastavu. Sadrži tri kategorije koje se odnose na stupanj upotrebe tehnologije u nastavi: replacement/zamjena, amplification/pojačanje ili transformation/preobrazba. Svi nivoi upotrebe tehnologije odnose se na utjecaj tehnologije na sva tri vida upotrebe: metode poučavanja, procese učenja te ishode učenja (Hughes, Thomas, Schaber, 2006). R.A.T. kategorije ne predstavljaju linearan put kojim bi se učitelji trebali razvijati, od zamjene preko pojačanja do transformacije, nego tehnologiju upotrebljavaju u isto vrijeme na različite načine, od kojih je preobrazba najteže ostvariva.

Unatoč tome, mnogi navedene tri kategorije razumijevaju kao ljestvicu, pa su se iz trostupanjske RAT ljestvice razvili i drugi modeli. $\mathrm{Na}$ internetu je vjerojatno najrašireniji četverostupanjski SAMR model (substitution/ zamjena, augmentation/obogaćivanje, modification/prilagodba, redefinition/ redefiniranje) (Puentedura, 2014). Usporedba obaju modela vidi se u Tablici 1.

\begin{tabular}{|c|c|}
\hline R.A.T. model & SAMR model \\
\hline $\begin{array}{l}\text { ZAMJENA } \\
\text { Tehnologija služi samo kao različito (digitalno) sredstvo } \\
\text { za postizanje istih ishoda učenja. Metode poučavanja, } \\
\text { procesi te ishodi učenja ostaju isti. }\end{array}$ & $\begin{array}{l}\text { ZAMJENA } \\
\text { Tehnologija je zamjena, bez ikakvog poboljšanja i } \\
\text { funkcionalne promjene u nastavi (npr. pisanje na } \\
\text { računalu). }\end{array}$ \\
\hline $\begin{array}{l}\qquad \text { POJAČANJE } \\
\text { Kategorija se fokusira na primjenu tehnologije koja je } \\
\text { pojačala trenutne metode poučavanja, procese te } \\
\text { ishode učenja. } \\
\text { Glavni su učinci povećana učinkovitost i produktivnost, } \\
\text { a ne preobrazba. }\end{array}$ & $\begin{array}{l}\qquad \text { OBOGAĆIVANJE } \\
\text { Tehnologija je zamjena ali s funkcionalnim } \\
\text { poboljšanjem (npr. upotreba tehnologije omogućava } \\
\text { dijeljenje, komentiranje, ispravljanje ...). }\end{array}$ \\
\hline \multirow[t]{2}{*}{$\begin{array}{l}\qquad \text { PREOBRAZBA } \\
\text { Odnosi se na korištenje tehnologije koja transformira } \\
\text { metodu poučavanja, procese učenja i/ili stvarni } \\
\text { predmet. } \\
\text { Ove promjene opisuju reorganizaciju u procesu učenja } \\
\text { učenika. }\end{array}$} & $\begin{array}{l}\text { PRILAGODBA } \\
\text { Tehnologija omogućava značajno preoblikovanje } \\
\text { zadatka (npr. program za obradu teksta zamijenimo } \\
\text { pisanjem bloga i mogućnošću javne objave } \\
\text { multimodalnog teksta). }\end{array}$ \\
\hline & $\begin{array}{l}\text { REDEFINIRANJE } \\
\text { Tehnologija omogućava stvaranje novih zadataka, koji } \\
\text { bez korištenja tehnologije ne bi bili mogući (npr. Pisanje } \\
\text { se pretvori u digitalno pripovijedanje). }\end{array}$ \\
\hline
\end{tabular}

Tablica 1. Usporedba R.A.T. i SAMR modela 
Učitelji koriste i ITL rubrike koje je razvio Microsoft. One se odnose na 6 područja učenja u 21. stoljeću: sudjelovanje, izgradnja znanja, samoregulacija, rješavanje problema svakodnevnog života i inovacija, sposobnost komuniciranja i korištenje IKT-a za učenje. Ovo područje usmjereno je na način na koji učenici koriste IKT: koriste li ga više za izgradnju znanja ili samo za dizajn proizvoda temeljenih na znanju. Naglašava se da izgradnja znanja omogućena IKTom mora podržati ciljeve učenja sadržaja predmeta, a ne učenje korištenja IKT-a. U tim kriterijima i smjernicama za ocjenjivanje aktivnosti učenja stupnjevi su uporabe tehnologije nešto drugačije postavljeni: IKT omogućava učenje osnovnih vještina, reprodukciju - IKT podupire stvaranje znanja - IKT omogućava stvaranje znanja - učenici su stvaraoci IKT rješenja (Microsoft-Partners in Learning, 2015). Kada su učenici autori IKT rješenja, aktivnost podupire rješavanje otvorenih (stvarnih) problema $\mathrm{i}$ istodobno inovativnost učenika. Učenici trebaju planirati rješenje za potrebe i želje ciljne grupe, u idealnom slučaju, ali nije nužno, ciljna publika može proizvod i koristiti.

Uvođenje tehnologije u nastavu dakle nije samo sebi svrhom već služi ostvarivanju postavljenih ciljeva, kako pojedinih jedinica učenja, tako i samog nastavnog predmeta. Kategorizacija pomaže stjecanju uvida u dosljednost ili nedostatak dosljednosti u tome kako su oblikovani ciljevi neke jedinice, kako je poučavana i kako je vrednovano znanje (Anderson i sur. 2016, str. 56).

\section{Metodologija}

U projektu Inovativno okružje za učenje uz podršku IKT-a prve godine projekta bilo je uključeno 20 razvojnih škola, a učitelji tih škola su sudjelovali u redovitim mjesečnim usavršavanjima na razini svoje škole i šire, u okviru projekta. Pritom su voditelji usavršavanja uočili da mnogi uporabi tehnologije $u$ poučavanju $i$ učenju pripisuju prije svega motivacijsku funkciju, bez dubljeg uvjerenja $u$ to da uporaba tehnologije može stvarno podupirati proces učenja $i$ omogućiti veću aktivnost učenika, a time razvijanje kompetencija i stjecanje znanja.

\section{Uzorak}

U travnju 2018. proveli smo stručno usavršavanje učitelja na daljinu: Planiranje nastave uz podršku IKT-a. Usavršavanje smo planirali u tri dijela, od 133 sudionika prisutna u prvome susretu, njih 71 predao je svoj primjer planiranja nastave uz podršku IKT-a. Te primjere smo koristili za analizu kvalitete planiranih aktivnosti. Sudionici nisu bili unaprijed obaviješteni o analizi, zato očekujemo da su predani primjeri stvarni odraz aktivnosti učitelja. Tablica (Slika 2) koju su predali učitelji, vodila in je u procesu planiranja te povezivanja ciljeva i aktivnosti.

\begin{tabular}{|l|l|l|l|l|}
\hline $\begin{array}{l}\text { Što želim da učenici } \\
\text { znaju? }\end{array}$ & $\begin{array}{l}\text { Kako će učenici to } \\
\text { postići ? } \\
\text { CILJEVI }\end{array}$ & $\begin{array}{l}\text { Koje alate će } \\
\text { učenici upotrijebiti? }\end{array}$ & $\begin{array}{l}\text { Kako ćemo } \\
\text { provjeriti i koja su } \\
\text { mjerila ostvarenosti } \\
\text { ciljeva? } \\
\text { KRITERIJI USPEHA }\end{array}$ & Izazovi, ocjenjivanje \\
$\begin{array}{l}\text { (glagol poomovoj ili drugoj } \\
\text { taksonomiji) }\end{array}$ & & & & \\
\hline & & & & \\
\hline
\end{tabular}

Slika 2. Prijedlozi za planiranje nastave podrškom IKT

Kada su učitelji u predložak zapisali više primjera, ili aktivnost podijelili na više dijelova uvažili smo onaj koji je iskazivao najsmisleniju i najtemeljitiju uporabu IKT-a, odnosno njezinu najveću dodanu vrijednost.
Iz uzorka smo izuzeli 1 primjer koji se odnosio na višeškolski program i 2 primjera informatike, gdje se radilo o učenju uporabe programske opreme (npr. Excel), uvažili smo primjere računalstva i drugih stručnih modula koji su 
aplikacije koristili za postizanje drugih ciljeva, ukupno 68 primjera, od toga 39 iz osnovne škole i 29 iz srednje škole. Uslijed malog uzorka u kategoriji srednje škole nismo dijelili gimnazije $\mathrm{i}$ srednje strukovne škole, a predmete smo grupirali u predmetna područja, kao što prikazuje Tablica 2.

\begin{tabular}{|c|c|c|c|c|c|c|c|c|c|}
\hline & $\begin{array}{l}\text { Razredna } \\
\text { nastava }\end{array}$ & $\begin{array}{l}\text { Slovenski } \\
\text { jezik }\end{array}$ & $\begin{array}{l}\text { Strani } \\
\text { jezici }\end{array}$ & Matematika & $\begin{array}{l}\text { Sport i } \\
\text { umjetnost }\end{array}$ & $\begin{array}{l}\text { Prirodoslovlje i } \\
\text { prirodoslovni } \\
\text { predmeti }\end{array}$ & $\begin{array}{l}\text { Društveno- } \\
\text { humanističko } \\
\text { područje }\end{array}$ & Struka & \\
\hline $\begin{array}{l}\text { Osnovna } \\
\text { škola }\end{array}$ & 14 & 4 & 6 & 4 & 5 & 2 & 4 & 0 & 39 \\
\hline \multirow[t]{2}{*}{$\begin{array}{l}\text { Srednja } \\
\text { škola }\end{array}$} & 0 & 3 & 6 & 3 & 1 & 6 & 2 & 8 & 29 \\
\hline & 14 & 7 & 12 & 7 & 6 & 8 & 6 & 8 & 68 \\
\hline
\end{tabular}

Tablica 2. Struktura uzorka primjera dobre prakse

\section{Analiza}

Za analizu predanih primjera upotrijebili smo tri kriterija s tri stupnja:

1. kriterij: planirane aktivnosti omogućuju i podržavaju postizanje postavljenih ciljeva, pri čemu smo promatranom primjeru dodijelili 0 bodova, ako aktivnosti nisu bile povezane $s$ ciljevima, te do 3 boda ako su ciljevi i aktivnosti bili potpuno poravnani i usklađeni.

2. kriterij (RAT model): planirana aktivnost znači zamjenu (1 bod), obogaćivanje ( 2 boda) odnosno transformaciju tradicionalne aktivnosti (3 boda).
3. kriterij (priređene ITL rubrike): aktivnost, uz primjenu IKT-a omogućava učenje osnovnih vještina ili reprodukciju (1 bod) - podržava, odnosno, omogućava konstrukciju znanja ( 2 boda učenici stvaraju IKT rješenje (3 boda).

Kod analize i pripisivanja postignutih stupnjeva po RAT ili ITL rubrikama bilo je iz zapisa ponekad teško detaljno odrediti stupanj uporabe tehnologije bez točnih uputa koje dobivaju učenici. Stoga smo se kod dodjele bodova koristili zapisanim ciljevima, dakle onime što su učitelji željeli postići planiranom aktivnošću, bez obzira na stvarnu provedbu u koju nemamo uvid.

\begin{tabular}{|c|c|c|}
\hline $\begin{array}{l}\text { Što želim da učenici znaju? } \\
\text { CILEVI } \\
\text { (glagol po Bloomovoj ili drugoj } \\
\text { taksonomiji) }\end{array}$ & $\begin{array}{l}\text { Kako će učenici to postići? } \\
\text { AKTIVNOST }\end{array}$ & $\begin{array}{l}\text { Koje alate će učenici } \\
\text { upotrijebiti? }\end{array}$ \\
\hline $\begin{array}{l}\text { Saznaju da električna sila djeluje na } \\
\text { daljinu i da je rezultat naboja. }\end{array}$ & $\begin{array}{l}\text { Za prikazani eksperiment (približavamo se } \\
\text { naelektriziranom plastičnom štapiću s } \\
\text { papirima) predviđaju što će se dogoditi, što } \\
\text { je uzrokovalo promjenu i objašnjavaju zašto } \\
\text { se promjena dogodila. }\end{array}$ & Go spiral \\
\hline $\begin{array}{l}\text { Otkrivaju da postoje dvije vrste } \\
\text { naboja. }\end{array}$ & \multirow{3}{*}{$\begin{array}{l}\text { Pomoću simulacije neovisno istražuju } \\
\text { odnose između nabijenih tijela. Rješavaju } \\
\text { zadatke na radnom listu. } \\
\text { Radeći zajedno u timu, provjeravaju } \\
\text { odgovore na radnom listu, ispravljaju } \\
\text { pogreške i ispunjavaju odgovore koji } \\
\text { nedostaju. }\end{array}$} & \multirow{3}{*}{$\begin{array}{l}\text { QR code scanner } \\
\text { (za dostup do simulacije) } \\
\text { Simulacija: } \\
\text { https://phet.colorado.edu/s } \\
\text { ims/html/balloons-and- } \\
\text { static- } \\
\text { electricity/latest/balloons- } \\
\text { and-static- } \\
\text { electricity sl.html }\end{array}$} \\
\hline $\begin{array}{l}\text { Smatraju da na nabijena tijela } \\
\text { djeluju privlačne ili odbojne sile. }\end{array}$ & & \\
\hline $\begin{array}{l}\text { Istražuju jesu li tijela nabijena ili } \\
\text { neutralna }\end{array}$ & & \\
\hline
\end{tabular}




\begin{tabular}{|l|l|l|}
\hline Izvode fizičke eksperimente. & $\begin{array}{l}\text { Par izvodi eksperimente s električnim } \\
\text { nabojima. Njih dvoje predstavljaju odabrani } \\
\text { eksperiment. }\end{array}$ & $\begin{array}{l}\text { Pribor za provođenje } \\
\text { eksperimenta. }\end{array}$ \\
\hline $\begin{array}{l}\text { Provjeravaju svoje znanje. } \\
\text { izvođenje eksperimenta. }\end{array}$ & $\begin{array}{l}\text { U parovima istražuju eksperimente na } \\
\text { internetu i planiraju svoj eksperiment s } \\
\text { električnim nabojima. }\end{array}$ & $\begin{array}{l}\text { You Tube } \\
\text { Pribor po izboru (može se } \\
\text { donijeti od kuće) }\end{array}$ \\
\hline $\begin{array}{l}\text { Predstavljaju fizičko znanje koje su } \\
\text { koristili u tumačenju rezultata i } \\
\text { razmišljanja koja su ih dovela do } \\
\text { zaključaka. }\end{array}$ & $\begin{array}{l}\text { U padletu dijele upute za eksperiment, svoj } \\
\text { film, nalaze i objašnjenja. }\end{array}$ & $\begin{array}{l}\text { Padlet } \\
\text { Daju povratnu informaciju drugoj dvojici. }\end{array}$ \\
\hline $\begin{array}{l}\text { Na temelju povratnih informacija } \\
\text { poboljšaju svoj rad. }\end{array}$ & Kahoot \\
\hline
\end{tabular}

Slika 3: Primjer, koji je po svim 3 kriterijima dobio sve bodove

\begin{tabular}{|c|c|c|c|}
\hline \multicolumn{2}{|c|}{ Primjer A } & \multicolumn{2}{|c|}{ Primjer B } \\
\hline $\begin{array}{l}\text { Što želim da učenici } \\
\text { znaju? } \\
\text { CILJEVI } \\
\text { (glagol po Bloomovoj ili } \\
\text { drugoj taksonomiji) }\end{array}$ & $\begin{array}{c}\text { Kako će učenici to postići ? } \\
\text { AKTIVNOST }\end{array}$ & $\begin{array}{l}\text { Što želim da učenici } \\
\text { znaju? } \\
\text { CILJEVI } \\
\text { (glagol po Bloomovoj ili } \\
\text { drugoj taksonomiji) }\end{array}$ & $\begin{array}{l}\text { Kako će učenici to postići } \\
? \\
\text { AKTIVNOST }\end{array}$ \\
\hline $\begin{array}{l}\text { 1. pronađu stranicu } \\
\text { Moja matematika } \\
\text { 2. unose korisničko } \\
\text { ime i lozinku } \\
\text { 3. računaju (zbrajaju i } \\
\text { oduzimaju) do } 10 .\end{array}$ & 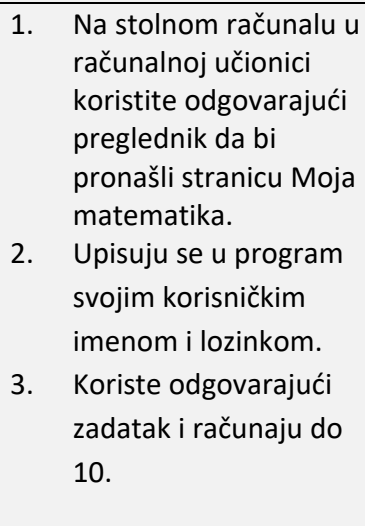 & $\begin{array}{l}\text { Učenici biraju ispravan } \\
\text { odgovor u aplikaciji } \\
\text { Kahoot }\end{array}$ & $\begin{array}{l}\text { Pomoću telefona odigrat } \\
\text { će kviz Kahoot. }\end{array}$ \\
\hline
\end{tabular}

Slika 4: Primjer slabo zapisanih ciljeva i aktivnosti

Pri zapisivanju ciljeva najviše teškoća imali su oni učitelji koji su obrazac upotrijebili za zapis strukture nastavnog sata u koracima. Oni su umjesto ciljeva koje bi ih učenici trebali ostvariti 
zapisivali aktivnosti pojedinog dijela sata. Tako u primjeru A sa slike 4, još uvijek možemo zaključiti da učitelj kod učenika želi razvijati digitalnu kompetenciju, ali primjer B evidentan je zapis ciljeva koji učitelja vode u nastavu, kod koje je u centru tehnologija, a ne učenik.

\section{Rezultati}

Rezultate analize prikazuje Tablica 3, iz koje je vidljivo da je po prvom kriteriju $61 \%$ analiziranih primjera doseglo najviši stupanj, dok smo kod uporabe drugog i trećeg kriterija ustanovili da većina postiže drugi stupanj (51\% odn. 59\%).

\begin{tabular}{|c|c|c|c|c|c|c|c|c|c|c|c|}
\hline & $\begin{array}{r}\text { podudaran } \\
\text { uporab }\end{array}$ & $\begin{array}{l}\text { je aktivnosti } \\
\text { a IKT podrža }\end{array}$ & $\begin{array}{l}\text { s planiranim } \\
\text { a planirane }\end{array}$ & $\begin{array}{l}\text { ciljevima, } \\
\text { ciljeve }\end{array}$ & & TT mode & & prilago & dene ITL ru & brike & \\
\hline $\begin{array}{l}\text { predmetno } \\
\text { područje }\end{array}$ & 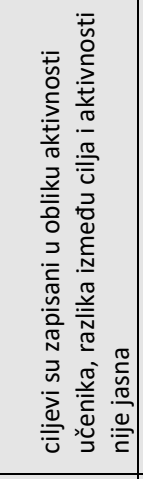 & 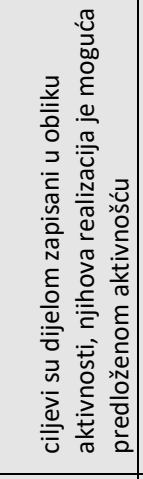 & 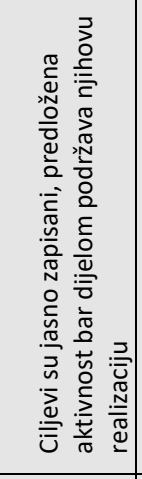 & 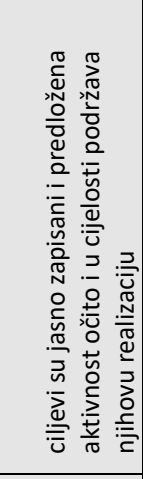 & 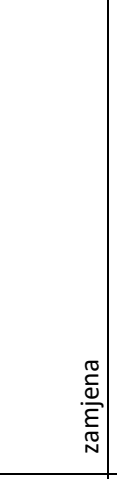 & $\begin{array}{l}: \\
: \\
0 \\
:=0 \\
: 0 \\
0.0 \\
0 \\
0 \\
0\end{array}$ & 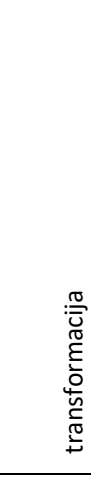 & 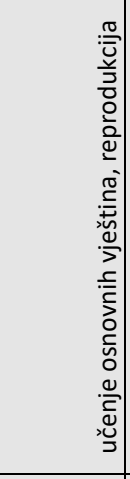 & 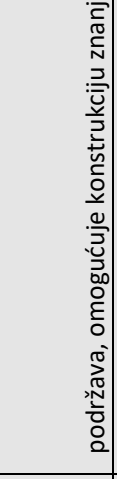 & & $\begin{array}{l}0 \\
0 \\
0 \\
0 \\
0 \\
0\end{array}$ \\
\hline & Ot & $1 \mathrm{t}$ & $2 \mathrm{t}$ & $3 t$ & $1 \mathrm{t}$ & $2 \mathrm{t}$ & $3 t$ & $1 \mathrm{t}$ & $2 t$ & $3 t$ & \\
\hline Broj primjera & 4 & 10 & 12 & 42 & 18 & 35 & 15 & 27 & 40 & & 1 \\
\hline
\end{tabular}

Tablica 3: Raspored analiziranih primjera s obzirom na korištene kriterije

U usporedbi tri korištena kriterija najviši stupanj smislene uporabe IKT-a ustanovili smo u kategoriji podudaranja aktivnosti i postavljenih ciljeva, a najmanji kod uporabe prilagođenih ITL rubrika, kako prikazuje Graf 1.

stupanj upotrebe IKT po ITL rubrikama

područje upotrebe IKT po modelu RAT

podudaranje aktivnosti i planiranih ciljeva

0

0,5

1

1,5

2

Graf 1: Usporedba rezultata s obzirom na korištene kriterije: Prosjek bodova (od 3) za svaki model

Od 9 mogućih bodova, analizirani primjeri su ih $u$ prosjeku dosegli 5,91, pri čemu između osnovne i srednje škole u prosjeku nema značajnijih razlika, kako prikazuje Tablica 4. 


\begin{tabular}{|r|r|r|r|r|}
\hline OŠ: 1-5 razred & \multicolumn{1}{|l|}{ OŠ: 6-7 razred } & OŠ - ukupno & \multicolumn{1}{|l|}{ Srednja škola } & prosječno ukupno \\
\hline 5,35 & 6,24 & 5,92 & 6,13 & 5,91 \\
\hline
\end{tabular}

Tablica 4: Prosječne ostvarene vrijednosti (max. 9 bodova)

Zbog specifičnosti učenika i nastave u nižim razredima osnovne škole 14 primjera smo izuzeli kod računanja prosječno postignutih bodova $s$ obzirom na predmetna područja i razinu obrazovanja u Tablici 5.

\begin{tabular}{|c|c|c|c|c|c|c|c|c|}
\hline \multirow{2}{*}{$\begin{array}{l}\text { Prosjek } \\
\text { bodova } \\
\text { za } \\
\text { primjere }\end{array}$} & \multicolumn{8}{|c|}{ Predmetno područje } \\
\hline & $\begin{array}{l}\text { slovenski } \\
\text { jezik }\end{array}$ & $\begin{array}{l}\text { strani } \\
\text { jezici }\end{array}$ & matematika & prirodoslovlje & $\begin{array}{l}\text { društveno } \\
\text { područje }\end{array}$ & $\begin{array}{l}\text { sport/sp. } \\
\text { odgoj }\end{array}$ & umjetnost & struka \\
\hline $\begin{array}{r}u \\
\text { osnovnoj } \\
\text { školi }\end{array}$ & 7 & 4,8 & 6 & 7 & 5,75 & 8 & 7 & / \\
\hline $\begin{array}{r}u \\
\text { srednjoj } \\
\text { školi }\end{array}$ & 4,3 & 6,6 & 6,6 & 6,2 & 5,5 & 8 & I & 6,12 \\
\hline prosjek & 5,65 & 5,7 & 6,3 & 6,6 & 5,63 & 8 & 7 & 6,12 \\
\hline
\end{tabular}

Tablica 5: Prosječne ostvarene vrijednosti prema predmetnim područjima

\section{Diskusija}

S gledišta projekta ustanovili smo da je uporaba prilagođenih ITL rubrika manje primjerena za vrednovanje uporabe tehnologije u nastavi, jer je samo jedan analizirani primjer postigao najviši stupanj, to je zamišljanje tehničkog rješenja za ciljanu publiku, kad su učenici u parovima planirali, samostalno proveli, snimili te objavili fizikalni pokus kojim su dokazali uporabu svog znanja fizike.

Pri uporabi RAT modela stupanj transformacije je doseglo više učitelja kojima je uspjelo pomoću tehnologije organizirati mogućnosti za učenje tako da bez uporabe tehnologije to ne bi bilo moguće. Zanimljivo je da su taj stupanj dosegli svi primjeri sportskog odgoja, a podroban pregled je pokazao da se radilo o snimanju i video analizi određenih elemenata s namjerom pravilnije izvedbe. Kao slabost RAT modela pokazalo se relativno nisko razlikovanje na drugom stupnju (jačanje odnosno obogaćivanje), jer je u tu kategoriju (prije svega zbog dodane vrijednosti automatizirane povratne informacije, analitike učenja odnosno elemenata igrifikacije) upao i veliki broj primjera koji su po ICL rubrikama dosegli tek prvi stupanj, dakle učenje osnovnih vještina i reprodukciju, a da se pritom nije bitno promijenio način učenja (npr. uporaba kartica za upamćivanje, kvizova za utvrđivanje i provjeru i sl.).

Taj element izrazito je prisutan u nastavi stranih jezika (prije svega u osnovni školi) i kod različitih predmeta u prva dva trogodišta osnovne škole, iako i tu nalazimo primjere dobre uporabe koji jako odstupaju od prosječne uporabe tehnologije u nastavi. Ispod prosjeka postignutih bodova su primjeri slovenskog jezika u srednjoj školi. Međutim, na temelju tri analizirana primjera, čije je prevladavajuće obilježje uporaba prezentacijskog alata PPT za pripremu govornih nastupa, ne možemo zaključivati o ispodprosječnoj uporabi tehnologije u nastavi. 


\section{Zaključak}

Promijenjene društvene, tehnološke i gospodarske okolnosti zahtijevaju promjene u obrazovanju gdje tehnologija postaje jedan od sve više samorazumljivih faktora poučavanja i učenja. Mada većina učitelja nema većih teškoća pri uporabi tehnologije za pripremanje nastave, okolnosti su drugačije kada se koristi tehnologiju za podršku procesu učenja. Stvaranje mogućnosti za učenje u kojima će učenici usvajati nova znanja i razvijati svoje kompetencije, od učitelja zahtijeva nov način razmišljanja, koji kreće od samog planiranja, a učiteljima treba alat pomoću kojeg mogu provjeriti je li planirana uporaba IKT-a smislena i pedagoški opravdana.

Analiza je pokazala da je za učitelje u projektu Inovativno okružje za učenje uz podršku IKT-a najprimjerenija bila RAT ljestvica, ali uz kontinuirano preispitivanje dodane vrijednosti koju primijenjena tehnologija donosi u proces poučavanja i učenja. Da bismo ustanovili jesu li planirane aktivnosti uistinu omogućile dosezanje postavljenih ciljeva, trebali bismo istraživanje nadograditi refleksijom učitelja i opažanjem nastave. Nadalje, kod analize predanih primjera bilo bi smisleno uključiti učitelje koji bi mogli potanko opisati vezu između ciljeva i aktivnosti, što bi moglo dovesti do promjena u vrednovanju pojedinih aktivnosti.

Smatramo da bi trebalo u projektu pripremiti detaljnije stručno usavršavanje usmjereno na unapređivanje artikulacije ciljeva i planiranja aktivnosti kojima se te ciljeve želi ostvariti te istovremeno učitelje poticati na transformaciju nastave, a ne puku zamjenu tradicionalnih aktivnosti tehnologijom. $U$ usporedbi smo ustanovili da je veći broj učitelja planirao primjere koji su proizlazili iz primjera dobre uporabe koje su upoznali na prethodnim stručnim usavršavanjima. Njihova javna objava može dakle imati značajan doprinos preobrazbi nastave, ali je potrebno učitelje poticati da primjere nadograde $i$ prilagode vlastitim učenicima i situacijama učenja te ih osnažiti i potaknuti na samostalno istraživanje, isprobavanje te dijeljenje vlastitih iskustava.

\section{Literatura}

Aberšek, B. i sur. (2016). Cognitive science in education and alternative teaching strategies. Cambridge: Cambridge Scholars.

Anderson, W. L. i sur. (2016). Taksonomija za učenje, poučevanje in vrednotenje znanja: revidirana Bloomova taksonomija izobraževalnih ciljev. Ljubljana: Zavod RS za šolstvo.

Bocconi, S., Kampylis, P., Punie, Y. (2012). Innovating Learning: Key Elements for Developing Creative Classroms in Europa. European Comission. [Elektronski]. August 2012.

http://ipts.jrc.ec.europa.eu/publications/pub. cfm?id=5181.

Francis, J. (2017). The Effe cts Of Technology On Student Motivation And Engagement In Classroom-Based Learning. University of New England. DUNE: DigitalUNE. Preuzeto sa http://dune.une.edu/theses/121.

Godzicki, L. i sur. (2013). Increasing motivation and engagement in elementary and Middle school students through TechnologySupported learning environments. Chicago: Sant Xavier University.

Hattie, J. (2018). Vidno učenje za učitelje: maksimiranje učinka na učenje. Griže: Svetovalno-izobraževalni center MI.

Hughes, J., Thomas, R., Schaber, C. (2006). Assesing Technology Integration: The RAT Framework. Society for Information Technology \& Teacher Education. Preuzeto sa https://www.learntechlib.org/primary/p/2229 $3 /$.

Mayer, R. E. (2013). Učenje s tehnologijo. O naravi učenja: uporaba raziskav za navdih prakse, Dumont, H., Istance, D., Benavides, F. (ur.), s. I.: ZRSŠ.

Microsoft-Partners in Learning (2015). 21CLD Student Work Rubrics. Microsoft Education. Preuzeto

\section{sa}


https://education.microsoft.com/gettrained/it I-research.

Mishra, P., Koehler, P., Matthews. I. (2006). Technological Pedagogical Content Knowledge: A Framework for Teacher Knowledge. Teachers College, Columbia University, Teachers College Record, Izv. 108, str. 1017-1054.

OECD (2013). Innovative Learning Environments, Educational Research and Innovation. Paris: OECD Publishing.

Puentedura, R. (2014). Technology In Education: An Integrated Approach. http://www.hippasus.com. Preuzeto sa http://www.hippasus.com/rrpweblog/archive s/2014/12/12/TechnologyInEducation_AnInte gratedApproach.pdf.

Redecker, C. (2017). European Framework for the Digital Competence of Educators, Punie, Y. (ed.), Luxemburg: Publications Office of the European Union.

Robinson, K., Aronica, L. (2015). Kreativne šole: Množična revolucija, ki preoblikuje izobraževanje. Nova gorica: Eno.

Stanojev, S. Florjančič, V. (2018). Digitalna pismenost srednješolcev. Založba Univerze na Primorskem. Preuzeto sa http://www.hippocampus.si/ISBN/978-9617023-78-7.pdf.

Stigler, W. J., Hiebert, J. (2009). The Teaching Gap: Best Ideas from World's Teachers for improving education in classroom. New York: Free Press.

\section{The evaluation of technology use in implementing innovative learning environments}

\begin{abstract}
Introducing ICT to schools is increasingly present not only in teaching but also in the learning
\end{abstract}

process. In the Innovative Learning Environment Supported by ICT project, the goal of introducing technology is to support the transformation of lessons in order to prepare learning opportunities in which students will acquire their knowledge and develop competencies. In doing so, teachers need knowledge and tools to assess whether ICT supported activities are appropriate for achieving the set goals and enable the transformation of lessons. In the paper, we explore three models that could help teachers making these important decisions. Based on the analysis of 68 examples of lessons plans, we propose that the R.A.T. model is the most appropriate for teachers in the 'Innovative ICT-supported learning environment' project. The benefit of the ICT implementation in teaching and learning process should be continuously monitored and evaluated.

Keywords: Innovative learning environment; ICT supported activities; R.A.T. model; ITL rubrics; SAMR model. 